\title{
John Locke'ta Sözcüklerin Kurulumundan Toplumun Kurulumuna Uzlaşım Unsurunun Rolü
}

\author{
Pınar Birlik Nisan
}

Özet: Locke'un dile ilişsin düşüncelerinin en ayırt edici yönü uzlaşımsallıktır. Locke'un dil anlayışında sözcükler ile ideler arasındaki bağlantının bir parçası olarak ortaya çıkan uzlaşımsallık unsuru, Locke'un sağın bilgiye erişmedeki amacında ilk elde her ne kadar dildeki bir yetersizlik olarak ortaya konmuş da olsa, gerek yine de bu imkana yaklaşmayı sağlayacak tek unsur olarak düşünülmesi, gerekse de iletişimin imkanını sağlamasıyla ön plana çıkmaktadır. Öyle ki, Locke'ta hakikat olsun, bilgi olsun, anlam olsun gerçek varoluşun bir iz düşümünü veren gösterilenlerde bulunduğu kadar, iletişimin birliğinde ve temelde de bu birliği kuran uzlaşımsallığın kendisinde bulunmaktadır. Dilin bu uzlaşımsal karakteri hiç şüphe yok ki, bizi dilin toplumsal yönünü ele almaya iten en önemli unsurdur da. Dolayssıyla onun dil anlayışındaki uzlaşım unsuruna ayrıca toplumla ilgili düşüncelerini de gözetecek bütünleyici bir bakış açısıyla da bakmak gerekir. Öte yandan dilin hem dünyayı, hem de içinde yaşadığımız toplumu kavrama ve tasarlama şekli ile yakından ilişkili olduğu da gözetildiğinde, Locke'un dili uzlaşım temelinde düzenleyerek sözcüklerin yanlış ve yanıltıcı soyut genelliğinden kurtulup 'sağın bilgiye' ulaşmak suretiyle ideal bir topluma ulaşmak istediği de varsayılabilir. Bu bakımdan çalışmamız bütünleyici bir bakış açısıyla, Locke'un hem sözcüklerin kurulumunda, hem de dil dolayımıyla toplumun kurulumunda "uzlaşım" unsuruna yüklemiş olduğu rolü ve sonuçlarını ortaya koymayı amaçlamaktadır.

Anahtar sözcükler: Sözcük, toplum, uzlaşım, bildirişim, sağın bilgi.

Abstract: The most distinguishing aspect of Locke's thoughts pertaining to language is conventionalism. In Locke's understanding of language, the factor of conventionalism emerging as a part of connection between words and ideas comes into prominence both through its being considered as the only element to ensure approaching this possibility and through its providing the possibility of communication although it has been presented as an insufficiency in language at once in his aim to obtain exact knowledge. So much so that, in Locke be it truth, be it knowledge or be it meaning, these exist in the unity of communication and in the conventionalism itself that essentially establish this unity as well as that they exist in those demonstrated which provide the projection of actual existence. This conventional characteristic of language, for sure, in the most significant element

Birlik Nisan, Pinar. (2017). John Locke'ta Sözcüklerin Kurulumundan Toplumun Kurulumuna Uzlaşım Unsurunun Rolü. Kilikya Felsefe Dergisi (2). ss. 69-95. 
that leads us to deal with the social aspect of language. Thus, it is necessary to analyze the factor of conventionalism in his understanding of language from an integrative perspective that will take into account his thoughts regarding the society as well. On the other hand, when it is considered that language is closely related to both the world and the way it conceives and designs the society in which we live, it can be assumed that Locke, by organizing the language on the basis of conventionalism, wanted to reach an ideal society through getting rid of the words' erroneous and deceptive abstract generality and obtaining exact knowledge. From this point of view, our study aims to reveal with an integrative perspective the role which Locke assigned to the factor of "conventionalism" both in organization of the words and in organization of the society thanks to mediation.

Keywords: Word, society, conventionalism, communication, exact information.

\section{Giriş}

Locke'ta dilin, yani kullanılmakta olan sözcüklerin en temel görevi bildirişim amacıyla düşüncelerin iletimini sağlamaktır. Fakat Locke, bunun yanı sıra dış dünyanın temsili söz konusu olduğunda, sözcüklerin aynı zamanda bilgi verici bir özellikte olması gerektiğini de düşünür. Dolayısıyla Locke, sözcüklerin kurulumunu, onların hem bildirişimi nasıl mümkün kıldıkları sorusu çerçevesinde, hem de şeylerin temsilini ne oranda sağlayabildikleri çerçevesinde incelemeye gider. Onun bu incelemesi, dil anlayışının en önemli yönünü “uzlaşımsallık” olarak ortaya koyar.

Locke'ta sözcüklerin zihnimizdeki ideleri imlediği düşünüldüğünde, onların kurulumunu incelemenin yolunun da idelerden geçmek durumunda olduğu açılık kazanır(Ott, 2004: 7). Locke bu bağlamda öncelikli olarak nominal öz- real öz ayrımına giderek, bilginin doğasını, türünü ve genişliğini anlayabilmek üzere, sahip olduğumuz idelerin bir kısmının basit, bir kısmının ise karışık olduğunun tespitini yapmakla başlar. Bu bağlamda Locke için gerçeklik, anlama yetisi için ancak idelerde ve ideler aracılığıyla ortaya çıkacak bir yapıdadır(Nayak, 2003: 23). Locke bu tespitleri doğrultusunda, sözcüklerin kurulumundaki uzlaşım unsurunu nominal öz ve real öz ayrımından hareketle ele alarak ideler üzerinden bir açıklığa kavuşturur. Böylece de bilgi, anlam, hakikat ve bildirişim söz konusu olduğunda "uzlaşım"ın rolünü açık bir şekilde ortaya koymuş olur. 
Dilin uzlaşımsal karakteri ise hiç şüphe yok ki, bizi dilin toplumsal yönünü ele almaya iten en önemli unsurdur. Dili incelediği gibi toplumu ve onun kurulumunu da inceleyen bir filozof olarak Locke'un görüşleri içerisinde, özellikle dil anlayışında ön plana çıkan uzlaşımsallık unsurunun onun toplum üzerindeki düşüncelerine olacak yansımaları da büyük önem taşıyacaktır. Nitekim dilimiz hem dünyayı, hem de içerisinde yaşadığımız toplumu kavrama ve tasarlama şeklimiz ile de yakından ilişkilidir. Bu bakımdan Locke'un, dilimizi uzlaşım temelinde düzenleyerek sözcüklerin yanlış ve yanıltıcı soyut genelliğinden kurtulup 'sağın bilgiye' ulaşmak suretiyle, ideal bir topluma, yani iyi düzenlenmiş bir topluma ulaşmayı arzuladığı da belirtilebilir.

Öte taraftan, Locke'ta sözcüklerin kurulumunda merkezi bir önemde duran bu uzlaşımsallık unsurunun toplumun inşasında da önemli bir rol üstlenecek olduğunu da belirtmek gerekir. Nitekim görülecektir ki, Locke'ta sadece sağduyulu bireyler, akılları ve iradeleri gereği ortak bir dilin uzlaşımsal olan bütünleştirici yapısında bir araya gelerek toplumu oluşturabilecektir.

\section{1) Sözcüklerin Kurulumunda Nominal Öz - Real Öz Ayrımı}

Locke, kullanılan sözcüklerin bildirişimi mümkün kılmasını öncelikle, idenin semiyolojik bir nesne haline gelmesinde görür. Locke için, her şeyden önce idenin semiyolojik bir nesne haline gelmesi ise, ideler ve sözcüklerin gerçekten varolan şeylerin ve olması gereken eylemlerin birincil ve ikincil göstergeleri olmaları olgusunda ve idelerin, zihnin, düşünme edimi içerisinde ilişkili olduğu gerçekliğin göstergeleri olduğu bağıntısında açıklık kazanır. Böylece, sözcükler ile şeylerin doğrudan olmayan, dolaylı imlemesinin, bu imlemenin şeylerin ideleri aracılığıyla mümkün olduğunu ifade ederken Locke'un, hem idenin gösterge karakterini ön plana çıkarmakta hem de bu dolaylı imleme dolayısıyla da, sözcüklerin kurulumundaki uzlaşım'a dikkat çekmekte olduğu görülür.

Sözcükler ise, Locke'ta hem basit idelerin, hem karışık kiplerin hem de tözlerin adı olabilmektedir. Bu adlar, imleme biçimleri bakımından ya da temsil ettikleri idelerin genetik farklılıklarına bağlı olarak, sözcüklerin kurulumundaki uzlaşımsallık bağlamında da göreceğimiz gibi, birbirlerinden ayrılacaktır(Altuğ, 2011:48). Dolayısıyla, Locke'un felsefesinde sözcüklerin kurulumundaki uzlaşım'ın rolünü inceleyebilmek için, onda idelerin türlerini ve gerçekliği temsil etme derecelerini 
belirleyen önemli bir ayrım olan nominal öz/real öz ayrımından hareket etmek gerekir.

İdelerin gösterge olarak taşıdıklarıözellikleri uzlaşımsallıkla ilişkileri çerçevesinde ortaya koyabilmek içinse öncelikle Locke'un nominal öz ve real öz ayrımlarının ne anlama geldiğini ve onların uzlaşımsallıkla olan ilişkilerini ortaya koymak gerekir. Locke'un öz'ü ne anlamda olmak üzere ele aldığına baktığımızda, onu bir şeyin her ne ise o olmasını belirleyen asıl varlığı olarak ifade ettiğini görürüz. Bir başka ifade ile Locke, şeylerin bilinebilir niteliklerinin kendisine bağlı olduğu, içsel ve genellikle (nesnelerde) bilinemez olan yapısını onların özü olarak belirler(Locke, 2004:299). Locke’a göre, bu tanım öz sözcügünü ifade etmekteyse de aslında real (gerçek) öz'ün kendisine işaret etmektedir (2004:299).

Öz'ün kendisine ilişkin olarak Locke'un yapmış olduğu ikinci bir belirleme ise nominal (adsal) özlere ilişkindir. Nominal öz ayrımı ise ona göre, şeylerin aldıkları adlar altında cinslere ve türlere göre gruplandırılmış bu adlar altında bulunan belli soyut idelere uygunluklarına göre yapılır. Buna göre, her cinsin ya da türün özü, genel ya da türsel adın yerini tuttuğu soyutideden başka bir şey değildir(2004:299). Locke'a göre akla daha uygun olan bu görüş, bütün doğal şeylerin, kendi duyulamaz bölümlerinden oluşan gerçek, fakat bilinemez bir yapısının bulunduğunu ve onları ortak adlar altındaki türlere göre gruplamak gerektiğinde birbirinden ayırt etmemizi sağlayan duyulur niteliklerin o yapıdan kaynaklandığını kabul edenlerin görüşüdür. Bu tanıma uyan öz ise, nominal (adsal) özdür.

Bu bakımdan nominal öz, gerçek varoluşa ait bir şey değil, zihnin bir gösterilen olarak kurduğu bir ide olmak durumundadır. Eş deyişle, nominal öz, kendisi altına konulan tikel şeyin varoluş koşulu değil de, onun bilinmesinin, yani tanınmasının bir koşuludur(Aaron, 1963: 210). O halde genel sözcügün temsil edeceği tözün de, türlerin özü, yani nominal öz olacağı açıktır. Ayrıca, gerçek varoluşa ait bir şey olmaması ve zihnin kendi kurduğu bir şey olması bakımından da nominal öz'ün uzlaşımsal anlam olarak karşımızda duracağı da net bir şekilde ortaya çıkar.

Bu bakımdan Locke'un bu söz konusu ayrımı, onun temsil anlayışında sözcüklerin ideler üzerinden dış dünyayı hangi oranda temsil ettiğini anlamak bakımından da oldukça önemli görünmektedir. 


\section{2) Sözcüklerin Kurulumunda Uzlaşımın Rolü}

Locke'un yapmış olduğu real öz- nominal öz ayrımından hareketle, ilk olarak basit idelerin gösterge karakteri incelendiğinde, öncelikle onlardaki ide-nesne imleme bağıntısının doğal olduğu, yani insan kararları ile değiştirilemez olduğu görülür. O halde, basit idelerin adları tamamen şeylerin varoluşundan alınırlar ve hiçbir şekilde imlemleri bakımından keyfi değildirler. Basit ideler, duyu nesneleri tarafından veya zihnin işlemlerinde edimsel olarak sunulur ve dolayısıyla da onlar, zihin ve gerçeklik arasındaki en dolaysız dolayımlar olurlar. Çünkü onlar, gerçek varoluşun duyularımızdaki doğrudan etkisi sonucu oluşmuştur. Ancak belirtilmesi de gerekir ki, onlar bir taraftan da dolayım'dırlar, çünkü duyusal algı, niteliğin kendisi de değildir. $\mathrm{O}$ halde, basit idelerin adlarının imlediği şey, dilin gerçekliğe temas ettiği noktadaki semantik birimlerdir. Açıktır ki buradan çıkaracağımız sonuç, basit idelerde, adların temsil ettiği özlerin nominal olamayacağı, bu adların imlemlerinin keyfi, uzlaşımsal, isteğe bağlı herhangi bir öğe içeremeyeceğidir. Locke, "basit idelerin adları, dolaysız biçimde imledikleri çıplak algıdan başka herhangi bir öze gönderimde bulunmazlar(Locke, 2004: 303)", diyerek zihnin herhangi bir öz meydana getirme gücüne sahip olmadığına dikkat çeker. Ona göre, zihin özü, kendisi üzerinde etkide bulunan şeylerin gerçek varlığı tarafından kendisine sunulduğu şekliyle almaktadır. O halde açıktır ki, basit ideler bizim tarafımızdan meydana getirilmezler, onlar bize verilirler.

Öte taraftan, basit ideleri imleyen adlara baktığımızda, onların salt sözel düzeyde kalınarak anlaşılamayacakları, bir başka ifade ile onların tamamen dil içi olmadıkları da belirtilebilir. Aksi halde basit ideler, Locke'un iddiasının aksine tanımlanabilirlerdi. Bilindiği üzere, tanım bir nitelikler çokluğunu gerektirmektedir, oysa basit ideler, tek bir nitelik içermekte ve bu özelliklerinden ötürü de tanımlanamamaktadırlar. Ancak basit idelerin tanımlanamamalarına karşın, duyusal bir imgede örneklenebilecekleri de unutulmamalıdır. Çünkü bu özelliklerinden ötürü, bir basit idenin adı, kaldı ki bu basit ide ister duyum isterse düşünüm idesi olsun, bilinçte kavranmadan önce anlaşılamaz(Nayak, 2003:43). Ancak bu tür idelere sahip olmak için, Locke'a göre, iç ve dış duyuya başvurmak gerekir; nitekim basit ideler edimsel olarak sunulmakla, somut bir deneyimdeki görünüşlerine dayanılarak edinilebilirler: "Bunlar bu şekilde alımlanmazlarsa, bu idelerin adlarından herhangi birini açıklamak veya tanımlamak için kullanılacak dünyadaki bütün sözcükler, bu adın temsil 
ettiği ideyi bizde asla meydana getiremez(Locke, 2004:112).

O halde, bir basit ide adının imlemini bilinir kılmanın tek yolu, zihinde bu ideyi meydana getirebilecek konuyu duyulara sunmak ve sözcüğün temsil ettiği ideyi edimsel olarak meydana getirmektir. Böylece real anlam düzeyinde kalan basit ide adları, imlemleri bakımından zihin dışının belirlenimi altında bulunmaları bakımından da dildeki uzlaşımsallığın alt sınırında kalmak durumunda kalır.

Locke, uzlaşımsal anlamın üst sınırına ise, karışık kip adlarını koyacaktır. Karışık kip adlarının ise öncelikle genel adlardan ibaret olduklarını belirtmek gerekir. Onların uzlaşımsal yapılarını incelemezden evvel, sözcüklerin genel idelerin imleri olarak nasıl kullanıldığı ve bir idenin nasıl genel hale gelebildiği ortaya konulmalıdır. Çünkü karışık kiplerde ide bileşimini bağlayan ve onu bir tür yapan şey ad olduğu gibi, onların özünü muhafaza eden ve onlara süreklilik verecek olan şey de addır. O halde, karışık kiplerin özü için zorunlu olan birliğin sürekliliği ve sabitliği de ortak kullanımda uzlaşımsal olarak kendisine verilen ad'a dayanmak durumunda olacaktır. Böylece Locke karışık kiplerin özü ile genel adlar arasında sıkı bir bağıntı kurmuş olur. Bu doğrultuda Locke'un genel adlara ilişkin düşüncelerinden hareket ederek, karışık kiplerin uzlaşımsal doğalarına bakmak daha uygun görünmektedir.

Locke'a göre varolan şeylerin hepsinin tikeller olmasına ve sözcüklerin de bu varolan şeylere uymaları gerekliliğine rağmen bütün dilleri oluşturan sözcüklerin büyük bölümü, dil kullanımının olması gerektiği kadar yararlı ve mükemmel hale gelmesi için genel'dir. Çünkü sadece adlardan yapılmış bir dil mümkün değildir. Kaldı ki bu mümkün olsa bile böyle bir dil ile iletişim kurmak mümkün değildir. Dolayısıyla genel terimlerin olması zorunludur, yani bu dilin doğasının dayattığı bir gerekliliktir. Öte taraftan, bilgimiz tikel şeyler üzerine kurulmuş olsa da, ancak şeyleri genel adlar altında türlere indirgediğimizde genişler. Açıktır ki, sadece tikel şeylerin adlarından oluşan bir dil ile tek tek şeyler dile getirilebilir olsa da, böyle yapıldığında hiçbir şey söylenemez, yani iletişim mümkün olmaz. Nitekim böyle bir dil, halihazırdaki deneyimimizin dışındaki herhangi bir şeye gönderimde bulunmamıza imkan vermez. Bu durumda bir şey söylemenin imkanı genel sözcüklerle mümkün hale gelmektedir. Bu bakımdan, hiçbir dilde, bütünüyle özel adlardan oluşan anlamlı bir cümle kurulamaz. Göstergenin genel olmadığı yerde, göstergenin gösterdiği şeyden kopup ayrılması ve dilin kendi başına, bağımsız bir temsil edici 
düzeye yükselmesi de mümkün görünmemektedir.

Öte taraftan Locke'a göre, karşılaştırmaları, sınıflandırmaları ve genellemeleri kaydedebileceğimiz bir özellikte olması bakımından dilimizin, bilgimizin iyileştirilmesi yönünde bir yarar sağlıyor olması da yine, dilin genel adlara sahip olması olgusunda açıklamasını bulur(2004:292). İşte tüm bu nedenlerden ötürü Locke için, özel adlar dışında, bir dilin bütün sözcükleri genel olmak durumundadır. Onların genelliğini sağlayan temeldeki unsur ise uzlaşımsallıktır, ortak kullanımdır. Locke'a göre, sözcükler ancak, uzlaşımsal olarak genel idelerin göstergesi yapılmakla genel hale gelirler. O halde ortaya çıkmaktadır ki, bir sözcük verilmiş bir şeyler ya da özellikler grubunu veya bir ideler grubunu imlemekle değil, fakat tek bir genel ideyi imlemek suretiyle genel hale gelmektedir.

Genel adlar ise, bu tanımlama biçimiyle temsil edici yeterliği içerisindeki tikel ideden başka bir şey değildir. Locke'a göre, genel ve tümel, şeylerin gerçek varoluşunda bulunmaz. Bunlar insanın kendi gereksinimleri için diğer insanlarla bir araya gelerek uzlaşımsal olarak ortaya koyduğu şeylerdir ve sözcük de ide de olsalar, yalnızca imlerle ilgilidirler. Sözcükler, genel idelerin imleri olarak uzlaşımsal olarak kullanıldıkları ve böylece birçok tikel şeye uygulanabilir oldukları zaman genel olurlar. İdeler de birçok tikel şeyin temsilcileri oldukları zaman genel olurlar. Fakat tümellik her biri kendi varoluşunda tikel olan şeylerin kendilerinde, hatta imlerinde genel olan sözcükler ve idelerde bulunmaz(2004:297). Bu noktada, bir idenin nasıl genel hale geldiğini anlamak ise önemlidir. Çünkü sözcüklerin kurulumunda uzlaşımsallık kriterinin kendisini en açık kılacağı nokta tam da burasıdır. Bunu anlamak içinse Locke'un tümeller'e ilişkin açıklamaları önem taşır.

Locke, tümeli ya da genel ideyi, pek çok tikeli uzlaşımsal olarak temsil edecek bir tikel ide olarak belirler. Her tikel ideye farklı bir ad vermemizi ve böylece de sonsuz sayıda adlar meydana getirmemizi engelleyen şey, Locke'a göre, zihnin tikel nesnelerden edinilmiş olan tikel ideleri gerek kendi kullanımı için gerekse de bildirişimin mümkünlüğü için, uzlaşımsal bir çerçevede genel hale getirmesidir. Locke'a göre, tümel ne zihnin dışında, şeylerin gerçek varoluşlarında bulunan ne de zihinden bağımsız tözsel formların intellektual dünyasında varolan bir şeydir. Genel ve tümel, şeylerin gerçek varlığına ait değildir, anlama yetisinin kendi kullanımı için meydana getirdiği buluşlar ve yaratımlardır(2004:296-297). Bu bakımdan 
da tümel, bizim yaptığımız bir şeydir. O halde tümel, şeylerin varoluşuna ait olmadığı gibi -varolan şey tikeldir-, kendi başına alındığında adlara da ait değildir. Bu haliyle de tümel, insan zihninin anlamlandırma etkinliğinin hem imkanı hem de bir yaratımı olarak görülmelidir. Locke'a göre tümeller, hem düşünsel, hem de dilsel etmenin birlikteliğinde, imleme (ya da genel olarak anlam verme ) ediminde kurulur. Ayrıca göstergenin, gösterdiği şeyden, yani gerçeklikten kopup ayrılmasının koşulu, imleme ediminde göstergenin genel ve tümel kılınmasıdır. Böylece tümel, insanın gösterge bilincinin bir parçası, gösterge kullanma yeterliğinin bir yönü olarak ve aynı zamanda da bu bilinç ve yeterliliğin oluşmasında rol oynayan bir etmen olarak kendini gösterir. Burada tümelin semiotik karakteri ortaya

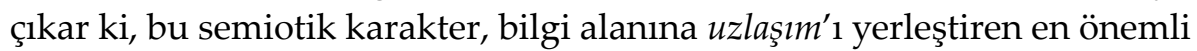
unsurdur da. Locke'a göre, şeylerin türlerinin özleri ve dolayısıyla şeylerin türlere ayrılması, soyutlama yaparak bu genel ideleri oluşturan anlama yetisinin bir işidir(2004:297). Dolayısıyla da varolan nesne türlerini doğada ve doğa tarafından bizim için ayrımlanmış, kendi başına varolan şeyler olarak değil de, zihnin oluşturduğu tümellerin bir işlevi olarak düşünmek gerekir.

Ancak burada dikkat edilmesi gereken husus, tümel'in uzlaşımsal olarak bizim kurduğumuz bir anlam olması dolayısıyla, 'uzlaşım'ın, adeta gerçek varoluşa bağımlı bir nesnelliği dışta bırakacak şekilde, bilme sistematiğimizi baştan aşağıya kuşatacak da olmadığıdır. Buradaki ayrım tümellerin nasıl oluşturulduğu ile ilgilidir. Duyu deneyimi dediğimiz şey her ne kadar tümelleri vermese de ve tabi ki de anlama yetisi onları, kendi dışında varolan bir şey olarak kavramasa da, tümellerin duyu deneyimine olan ihtiyaçları göz ardı edilemez. Nitekim tümeller, deneyimde verilmiş olandan soyutlama ile, yani nesnelerde gözlemlenen bağıntı ve benzerliklere göre kurulurlar. Bir başka ifade ile, zihin çeşitli zamanlarda çeşitli nesnelerde gözlemlemiş olduğu bir görünüşe dikkat yöneltir, onu ayrı düşünür ve bu görünüşü bu türden bütün görünüşlerin temsilcisi yapar. Bu bağlamda genel ide, deneyimin yol göstericiliğinde gerçekleştirilen bir eleme işleminin ürünü olarak karşımıza çıkmaktadır.

Burada, anlam'ın zihinden tamamen bağımsız bir gerçeklik dünyasına ait olduğu şeklinde bir nesnelliğe bağlanmadığının da altının çizilmesi gerekir. Her ne kadar Locke'un ifadelerinde gerçek varoluşa bir gönderim söz konusuysa da, tümel'i bilmenin, dışsal olarak varolan bir doğal türün özünü bilmek olmadığı da açıtır. Fiziksel nesnelere ilişkin bir temasımızın olabilmesinde tek aracımız olan duyum, bize doğadaki 
şeylerin iç kuruluşunu, yani real öz'ünü vermez. O halde, nesneyi bilme ve nesne hakkında konuşma, deneyimde bulgulanabilir olan niteliklerin de ötesine geçemez. Locke'un da dediği gibi, deneyim aracılığıyla, doğadaki benzerlik ve ayrılıkların ayırtına varırız. Fakat bir genel ide ile diğeri arasındaki ayrımı, karar veya uzlaşımla biz yaparız. Eş deyişle, doğadaki benzerlikler temelinde ve tabi ki de özgür istememizle belli nitelikleri seçeriz ve onlarla bir öz kurarız.

Gelinen noktada Locke'un real öz ve nominal öz arasında yapmış olduğu ayrım önem kazanır. Nitekim genel sözcügün temsil ettiği soyut ide $^{1}$, yani genel ad yukarıda ifade etiğimiz şekliyle türün özü sayılır. Ancak bu öz, şeylerin içsel fakat bilinmeyen kuruluşu olarak real öz'ü değil, fakat nominal özü'dür. Nominal özün aslında tam da 'uzlaşımsal anlam'ın kendisi olduğu hatırlandığında, deneyimin kılavuzluğunda genel bir sözcügün ne anlama geldiğini kararlaştırdığımız şeyin 'tümel'in kendisi olacağı da açıklık kazanır.

Bu noktada bir de tümellerin, teoloji, hukuk, politika ya da doğa felsefesi hakkında konuşabilmemizi sağlayan ve genel olarak da bilimi mümkün kılan kavramlar haline gelmesinde, uzlaşımsallığın nasıl bir rol oynadığına bakılmalıdır. Nitekim, bize bu alanlar hakkında konuşabilme imkanı veren tümeller açıktır ki, gelip geçici ve değişken özlerden ibaret olamaz. Onlar deneyimde olup biten her türden değişmeye karşılık, sabit kılınmış ve değişmez anlamlar olarak kalmak durumundadırlar. Locke, tümelleri "varedilemez ve bozulamaz özler, ebedi ve kalıcı özdeşlikler" olarak belirterek onların nesnelliğine işaret eder. Ancak daha önce de belirttiğimiz gibi bu nesnellik yalnızca anlamca sabit kılınmış ve kalıcı olmaktan ibarettir; yoksa onlar gerçek varoluşun bir türevi değildir. Nitekim Locke'a göre, real şeyler ve olaylar sürekli değişmesine karşın, soyut ideler, yani özler değişmezdir. Locke'un gerçek şeylerin ve olayların sürekli değişen dünyasına karşılık soyut idelerin değişmezliği öğretisi, dilin uzlaşımsal karakterinin bir özelliği olarak karşımıza çıar. Eş deyişle, soyut idelerin değişmezliği öğretisi, bu ideler ile onların göstergeleri olan belli sesler arasında uzlaşımsal olarak kurulmuş olan bağıntıda temellenir ve bu uzlaşımsallık temelinde aynı ad hep aynı imleme sahip olduğu sürece de daima doğru olarak kalır.

\footnotetext{
1 Soyut ide, genel sözcük kullanıldığında kastedilen anlamdır. Genel adlar, tikel varlıklarla bir bağıntıya sahip olduklarında, soyut ideler onları birleştiren aracılardır. Böylece şeylerin türlerinin özü, bizzat türleri kendisine göre belirlediğimiz ortak karakterler toplamı olan soyut ideden (genel ad) başka bir şey değildir.
} 
Böylece soyut idelerimizin, genel sözcüklerimizin ve tümelin uzlaşımsallık temelinde nasıl kurulmuş ve sabitlenmiş olduğunu gördükten sonra, şimdi de uzlaşımsal anlamın üst sınırında yer alacak karışık kiplerin adlarını daha yakından incelemeye geçebiliriz. Daha önce de belirttiğimiz gibi, karışık kiplerimizin adları genel olduklarından, şeylerin her birinin kendine özgü özü bulunan türlerinin yerini tutarlar. İşte bu türlerin özleri de, kendilerine birer ad verilmiş soyut idelerdir(Nayak, 2003:78) Burada söz konusu olan yeni bir ide yapımı değil, daha önce zihinde bulunan ideleri birleştirme işidir. Bu birleştirme işi, Locke'a göre zihinde üç aşamalı olarak gerçekleşir: öncelikle belli sayıda ide seçilir, bunların arasına belli bir bağlantı yerleştirmek suretiyle hepsi tek bir idede toplanır ve son olarak da bunların bileşimi bir ad ile bağlanır(Locke, 2004:308). Görülebileceği gibi her üç aşama da insanların özgür istemeleri çerçevesinde ve uzlaşımsal bir şekilde gerçekleştirilen bir yapıdadır. Bu bakımdan da onların basit idelerden tamamen farklı bir konumda bulunduğu belirtilmelidir. Nitekim, hatırlanacağ1 üzere, zihinde basit ideleri yapma gücü yoktu ve zihin sadece kendini etkileyen gerçek varlıkların kendine sunduğu şekliyle basit ideleri almaktaydı. Oysa karışık kip adlarını oluşturan ideler, doğadaki özgün örneklerinden bağımsız olarak uzlaşımsal bir şekilde bir araya getirilebilmeleriyle, bu türün herhangi bir bireyinin varoluşundan önce de yapılabilir bir nitelik sergilerler. Nitekim Locke'a göre, karışık kiplerin özleri, zihin tarafından keyfi biçimde, herhangi bir dışsal kalıba veya gerçek varoluşa bağlı olmaksızın meydana getirildiği unutulmamalıdır(2004:307-308).

Karışık kiplerin oluşumuna ilişkin Locke'un önemle dikkat çektiği birkaç husus, onların uzlaşımsal doğalarını ve gerçek karakterlerini anlamak açısından büyük önem taşır. Bunların en önemlilerinden biri, karışık kiplerin bireysel insan zihinleri tarafından uzlaşımsal olarak işlenip biçimlendirilmiş bileşimler olsa da, gelişigüzel bir biçimde değil de, dilin gereklerine uygun olarak meydana getirildikleridir. Bir diğeri ise, karışık kiplerin özlerinin şeylerin nesnel doğaları tarafından belirlenmeyip, bildirişime elverişlilik ve yararlılık bakımınca bireysel iradeler tarafından, dil içinde biçimlendirildikleridir. Böylece Locke'un dilin anlamı yapılandırması konusundaki düşünceleri, büyük ölçüde keyfi ve toplumsal bağlamla ilgili bir konu olarak karşımıza çıar(Dawson, 2007: 287). Nitekim farklı dillerde birbirine çevrilemeyen sözcükler bulunması olgusundan hareket eden Locke, her dil topluluğunun kendine özgü değer ve gelenek-görenek çerçevesi içerisinde anlam ürettiğini belirtmektedir: "Bir ülkedeki insanlar, gelenekleri ve yaşama tarzları yüzünden, başka 
ülkedeki insanların özgül ideler içinde toplamadıkları birçok bileşik ideler yapma ve bunlara adlar verme gereği duymuşlardır(Locke, 2004:309310)."

Böylece Locke'ta evrensel olmayan kavramların anlamlarının toplumdan topluma değişiklik göstermesinin ana nedeni, onların oluşumundaki uzlaşımsallıkların birbirinden farklı değer ve gelenekgörenekler çerçevesinde gerçekleşmesi olduğu ortaya çıkar. O halde kavramlara ilişkin anlamlar, sadece ortak bir toplumun uzlaşımsal üretimi olmalarından dolayıdır ki, kullanıldıklarında iletişimi mümkün kılarlar. Yine Locke'un, 'kavram' (notion) olarak adlandırdığı ahlaki, hukuki, dini vb. sözcükleri oluştururken, zihnin her ne kadar özgür olsa da, yine de bunu toplumun ortak yaşam biçiminin belirlediği bir uzlaşımsallık içerisinde olmak üzere belli sınırlar içerisinde yaptığını ima ettiği de görülür:

\begin{abstract}
“(..) karışık kiplerde, en azından onların en önemlileri olan ahlaksal varlıklarda, özgün örneklerin zihinde bulunduğunu düşünürüz ve tikel varlıkların adlar aracılığıyla ayırt edilmesinde onlardan yararlanırız. Karışık kip türlerinin özlerine kavram (notion) gibi özel bir ad verilmesinin buradan, bunların nesne idelerine göre anlığa daha özel biçimde bă̆lı oluşlarından geldiğini saniyorum(2004:311-312)".
\end{abstract}

Öte taraftan Locke'un, karışık kiplerin adlarının da bizi zihnin ötesine, yani zihinlerin üzerinde uzlaştığı bir yapının ötesine götüremeyeceğini ifade ederken de yine onlardaki uzlaşımsallığı ön plana çıkardığına tanık olunur(2004:311). Nitekim baktığımızda, karışık kiplerde ide bileşimini bağlayan ve onu bir tür yapan şey nasıl ki ad ise, karışık kiplerin özlerini muhafaza eden ve onlara süreklilik veren şeyin kendisi de ad'tır. Locke'un ad'ların oluşumundaki uzlaşımsallığa karışık kipler kapsamında şöyle dikkat çektiği görülür: “(...)karışık kiplerin özü için zorunlu olan birliğin sürekliliği ve sabitliği, ortak kullanımda kendisine verilen ad'a dayanır(2004:310-311)."

Böylece Locke'un dile ilişkin görüşlerinde, karışık kip adlarının imlemlerinin, uzlaşımsal anlamın nasıl ve ne şekilde üst sınırını oluşturduğu da bir açıklık kazanmış olur. Karışık kiplerin idelerini, doğadaki bileşimleri içeren kalıplara göre bir doğrulama ya da düzeltme imkanı olmadığından da, onlarınözlerisöz konusu olduğunda, adın anlamıbiricikölçütve arketip 
olmak durumundadır(Altuğ, 2011:50). Ayrıca açıktır ki, karışık kipler söz konusu olduğunda, onlarda bir real öz ayrıştırmak da mümkün değildir. Karışık kiplerde öz, tamamıla uzlaşımsal bir şekilde meydana getirildiği içindir ki, real varoluşa dair hiçbir gönderme içermez. Bu bakımdan karışık kiplerde real öz, deyim yerindeyse tanımı içerisinde eksiksiz bir biçimde ifade edilmiş olan nominal öz'dür sadece(Nayak, 2003:64). Kaldı ki nominal özlerin de doğruluklarını sürdürmesi hatırlanacağı gibi, üzerinde uzlaşıma varılmış olduğu haliyle aynı adın hep aynı imlemi taşımayı sürdürmesine bağlıydı. İşte Locke, söz konusu olan bu nominal özlerin doğruluklarını sürdürmesinin, yani aynı adın hep aynı imlemi taşımayı sürdürmesine bağlı olmasının bir kanıtını da, karışık kiplerde öncelikle adın öğrenilmesi olgusunda bulur. Ona göre, karışık kiplerde ve özellikle bunların en içeriklileri olan ahlaki sözcüklerde, genellikle, önce sesler öğrenilir; sonrada bu seslerin hangi bileşik ideleri temsil ettiklerini öğrenme işi ya başkalarının açıklamalarından beklenir ya da insanın dil kullanımına ilişkin kendi gözlem ve çabalarına bırakılır(Locke, 2004:312313).

O halde karışık kipler söz konusu olduğunda, dil dışına bir gidipgelme söz konusu olamayacağına göre, çoğu zaman belirsiz ve bulanık imlemlere sahip olanlarda bütün tartışmanın bir sesin anlamı üzerinde döneceği kabul edilebilir. Bu tür seslerin imlemlerini sınırlamada, ayırt etmede ya da değiştirmede belli bir ölçüt veya sınır bulunmadığı için, onlar daima çok anlamlılığa da açık dururlar.

Locke'un karışık kiplerin oluşumunda uzlaşımsallığı ön planda tutan görüşlerinin, onların özellikle ahlak alanına ait olanlarda rasyonel kuruluşlarının gözden kaçırıldığına dair olmak üzere kimi zaman eleştiriye tabi tutulduğunu gören Altuğ'un Dile Gele Felsefe adlı yapıtında, Locke'un görüşlerinden hareketle bu eleştiriye vermiş olduğu yanit, özellikle anlam söz konusu olduğunda bizi bir kez daha uzlaşımsallı̆̆ dilin merkezindeki unsur olarak görmeye iter: "Karışık kiplerin rasyonel kuruluşu, böyle bir şeyi kabul edecek olursak eğer, ancak dilin mantığ1 tarafından oluşturulmuş olabilir. Unutulmamalı ki, dilin gerisinde akıl değil, uzlaşım vardır. Sonuçta Locke, sözcüklerin anlamının, özellikle karışık kipler söz konusu olduğunda, onların kullanımını yöneten uzlaşımlara bağlı olduğunu apaçık görmüştür(Altuğ, 2001:51)."

Locke'un sözcüklere ilişkin incelemesinde şimdi bir de tözlerin adı olabilen sözcüklerin durumlarına bakılmalıdır. Nitekim Locke'un, imleme 
biçimleri söz konusu olduğunda basit idelerin ve tözlerin adlarını bir yana, karışık kiplerin adlarını ise diğer yana koyduğu görülür. Geldiğimiz noktada basit idelerin adlarının tamamen şeylerin varoluşundan alınması bakımından uzlaşımsal hiçbir öğeye yer vermeyen bir yapıda olduklarını, karışı kiplerin adlarının ise aksine, ideleri tamamen keyfi (arbitrary) biçimde temsil eden yapılarından ötürü uzlaşımsal anlamın üst sınırını teşkil eden bir yapıda olduklarını gördük. Peki tözlerin adları söz konusu olduğunda durum ne olacaktır?

Locke tözlerin adları söz konusu olduğunda, onların ideleri tamamen keyfi bir biçimde değil de bir kalıpla (pattern) ilişkili olarak imlediklerini ifade eder (Locke, 2004:300). Ona göre, basit idelerin ve tözlerin adları, dolaysız biçimde imledikleri zihindeki soyut idelerle birlikte, aynı zamanda kökensel kalıpların kendisinden türediği gerçek varoluşu da ima ederler. Oysa karışık kiplerin adları zihindeki idede son bulur ve daha fazla bir düşünceye götürmez(2004:302).

Locke'un basit idelerin, karışık kiplerin ve tözlerin adları hakkında yapmış olduğu bu açıklamanın dilin hem gerçekliğine ilişkin hem de ondaki uzlaşımsal anlam ile real anlam arasındaki sınırların belirlenmesine ilişkin bir takım içerimler taşıdığı açıktır. Ayrıca görülebileceği gibi, salt biçimde uzlaşımsal anlam sadece karışık kipler için söz konusudur. Karışık kiplerin özleri olarak işaret ettiğimiz anlam, dilin gereklerine uygun bir biçimde ve bildirişime elverişlilik ve yararlılık sağlaması gerekliliği göz önünde tutulmak kaydıyla tamamen uzlaşımsal bir biçimde, yani herhangi bir dışsal kalıba ya da gerçek varoluşa gereksinim duymadan meydana getirilmektedir. Oysa töz adlarının imlemleri, tıpkı basit idelerin adlarının imlemleri gibi, zihinde son bulmayıp zihin dışına gidip-gelmekte ve bir real anlam talebiyle de ortaya çıkarlar. Ancak bununla birlikte, Locke için töz adlarının imlemélerinin daima ikili bir yönelme taşıyacağı da unutulmamalıdır. Çünkü Locke töz adları söz konusu olduğunda, bu tür idelerimizin unsurlarının basit ideler olmasından dolayı, töz idelerimizi adlandırdığımız sözcüklerimizin anlamlarının kısmen şeylerin gerçekliğine dayandığını düşünür. $\mathrm{O}$, şeylere ilişkin idelerimizin, töz olarak adlandırdığımız bir temeli olduğunu kabul eder. Bir başka ifade ile, tözlere ilişkin bilgimiz, onun tek bir ad altında topladığımız birçok basit idenin duyulur niteliklerinin bir karışımı olduğu şeklindedir. İşte tam da bu bakımdan töz adları imlemeleri bakımından ikili bir yönelme ile karakterize olur. Böylece onların doğrudan imledikleri şey, zihnin bireysel tözlere ilişkin olarak kurmuş olduğu genel tasarım yani soyut ide iken, 
dolaylı biçimde imlediği şey ise gerçek varoluşlar olur. Tözlerin özleri (ad ve soyut ide eşleşmesi olarak nominal öz), nihai olarak bizim kurduğumuz bir şey olmakla birlikte, kendilerinde bir real varlık varsayımı da taşırlar. Onlar gerçek varoluştan alınmakla ona uygun düşerler. Bu demektir ki, tözleri adlandırdığımız sözcüklerin anlamları gerçek varoluşlarına geri götürülebilir. Eş deyişle, bu adların nesneyi gösteren tanımları yapılabilir. Fakat öte yandan, töz adlarının aynı zamanda sözel tanımlamaları da yapılabilir. Burada dilin uzlaşımsal karakteri bir kez daha kendini gösterir. Çünkü, insanların bir adın anlamına uzlaşımsal olarak dahil ettikleri nitelikler çokluğunun, yani soyut ideyi oluşturan üzerinde uzlaşılmış tüm niteliklerin eksiksiz bir dökümü yapılmak suretiyle de ad real olarak tanımlanabilir. Locke şöyle demektedir:

\begin{abstract}
“Nesnelerde, benim adsal öz dediğim soyut idelerinden ayrı olarak bir gerçek özden de çok söz ettiğim doğrudur. Bu gerçek öz ile demek istediğim şey, adsal özde bir araya gelen bütün özelliklerin temelinde bulunan ve adsal özle değişmez bir ortak varoluş içinde bulunan gerçek yapıdır. Gerçekte nesnelerin gerçek özüyle ilgili olarak, onun ne olduğunu bilmeden, yalnızca varolduğunu varsayarız, fakat yine de nesneleri türlere bağlayan şey, temelinde ve nedeni olarak o gerçek özün bulunduğu kabul edilen adsal özdür. Nesneler adsal öze göre tür ve cinslere ayrılır. Çünkü türün imi olan adın imlediği şey yalnızca odur. Demek bizim genel adlarla belirlediğimiz nesnelerin türlerini, bu adın onun bir imi olarak düşünüldüğü ideden başka bir şeyin belirlemesi mümkün değildir. Bu ideye adsal öz diyoruz(2004:299-300)."
\end{abstract}

Böylece Locke'un dil ve gerçeklik arasında kurmaya çalıştığ 1 ilişkinin, töz adlarının imlemesi söz konusu olduğunda, semantik bakımdan, uzlaşımsal anlam ile real anlam arasında bir gidip-gelme ile karakterize olduğu açık bir şekilde ortaya çıkar. Locke'un nominal öz ve real öz çerçevesinde dil ve gerçeklik alanı arasında kurmaya çalıştığı ilişki, görülebileceği gibi töz adları söz konusu olduğunda deyim yerindeyse tam olarak orta noktasını bulmuş gibidir. Çünkü açıktır ki, hakikat/ bilgi/anlam, bireysel olan'dan bağımsız "nominal öz" ile bireysel olana ait bilinemez "real öz" arasındaki asla kapatılamayacak olan mesafeden başka bir yerde bulunamayacaktır(Altuğ, 20011:53). Evreni oluşturan bireysel tözlerin real özlerinin, insanın duyularına ve düşünsel bakışına kapalı olduğu göz önüne alındığında, hakkında konuşabileceğimiz biricik özlerin, dil içerisinde uzlaşımsal olarak işleyip yaptığımız özler olduğu 
açıklık kazanır. Bu bakımdan, töz adlarının gönderiminin doğrudan nominal özlere ilişkin olduğu da ifade edilebilir. Ancak altı çizilmelidir ki, gerçeklik hakkında konuşan dil, yalnızca kendisi üzerine konuşan, yalnızca kendi kendisine gönderen bir dizgeden ibaret de değildir. Unutulmamalıdır ki Locke’a göre, dil-dışı gönderim bir olgudur ve bunun nihai temeli de duyuların etkileniminde bulunur. Bu bakımdan Locke, töz adlarının imlediği bileşik idelerin, doğada birlikte varoldukları gözlemlenmiş olan basit idelerden oluşmak durumunda olduğunu önemle vurgular. Çünkü töz adlarının imlemlerinin insanların ideleriyle olduğu kadar, şeylerin gerçekliği ile de uyuşmaları gerekir. Kaldı ki, bunu mümkün hale getirecek olan da, bireysel tözlerin duyusal algıda tanınmış olan nitelikleri, yani eş deyişle basit idelerdir. Edimsel olarak elde etiğimiz basit ideler ile, şeylere uygunluğun nihai güvencesini garanti altına almış oluruz. O halde açıktır ki, töz adları duyularımız tarafından doğrulanabilir olan şeyi, yani gördügümüz üzere duyuda görünüşe çıkan bir basit ideler kümesini imlemektedir.

Töz adlarında meydana gelen karışıklıkların ise, büyükölçüde tözlerin real kuruluşlarına nüfuz edemeyişimizden ve bilgi eksikliğimizden kaynaklandığı düşünüldügünde, Locke'un töz adlarını imlemleri bakımından daima yetersiz ve eksikli görmesi anlaşılırdır. Fraser'ın bu konuda, "bireysel şeylerin nominal özleri olan kavramlarımız, ulaşılamaz olan real özlere doğru ilerlememize yardım ederler; bu real özler idealler olarak, bizim intellektüel ilerlememizin kaynaklarıdırlar ve onlarda fiziksel evrenin sırları saklı olarak kalmaktadır(Fraser, 1894:31),derken, insanın bireysel tözlereilişkin bütün soyut idelerinin, edimselgerçekliğe tam uygun olmamakla birlikte, yine de bizim kurduğumuz bu anlamların, duyuların koyduğu sınırlar altında mümkün olduğu ölçüde real olabileceğine işaret etmekte olduğu ortadadır. Locke'un, göstergeler teorisiyle amaçladığ 1 şeylerden birinin de, gerçeklik hakkında konuşmanın mümkün olduğu ölçüde bilgi verici ve real hale getirilebileceği yolları göstermek olduğu düşünülürse Fraser'ın bu ifadelerinin doğruluğu açıklık kazanır.

Bu durumda dilin uzlaşımsal bir alan olmasının önemi bir kez daha ortaya çıkar. Nitekim, gördügüumüz üzere hakikat olsun, bilgi olsun, anlam olsun gerçek varoluşun bir iz düşümünü veren gösterilenlerde bulunduğu kadar, iletişimin birliğinde ve temelde de bu birliği kuran uzlaşımsallığın kendisinde bulunmaktadır. 


\section{3) Dil, Toplum ve Uzlaşım Arasındaki İlişkiler}

Locke' un dile olan ilgisi sadece Deneme ile sınırlı değildir Onun dile olan bu ilgisi, bütün yazılarındaki motiflerin ortaya çıkışında iş gören ve arkası çektikçe gelen bir iplik gibidir(Dawson, 2007:277). Bu, en açık şekilde onun toplumsal içerikli metinlerinde görülebilir. Bu söz konusu metinlerde Locke'un dil konusuna öncelikli bir yer vermesinin nedeni, dilin kullanıcıları üzerindeki acımasız etkilerini görmüş olması ile yakından ilgilidir. Bizim de bu duyarlılığı hissedebilmemiz ancak, Locke'un dilin belirsizliği üzerindeki ısrarını anlayabilmemiz ile mümkündür. Çünkü dilin bu belirsizliği üzerindeki ısrar Locke'a göre, insan hayatını ve toplumu ele geçirerek baskı altında tutan tüm mekanizmaları sorgulayacak ve insanlığı ilgilendiren her türlü durumdaki belirsizliği, düzensizliği ve de kesinliksizliği bir düzene koymayla ilgili bize bir fikir verebilecektir(Locke, Deneme'nin İng. Versiyonu:248-249) ${ }^{2}$. Locke'ta toplumla ilgili konularda dilin işlevselliği ile ilgili bundan daha açık bir ifade bulmak oldukça güçtür. Dolayısıyla Locke'un bu umutsuz görünen kavşağın ötesine, yani dilin belirsizliğinin ötesine uzlaşımsallık boyutuyla uzanan bir soruşturmayı amaçlaması yine de kendi içinde tutarlı görünmektedir. O halde, sözcüklerin kurucu ve teşkil edici gücünde uzlaşım'ın rolünü, bir de onun anlayışında toplumun kurulumuna ve devamına olabilecek muhtemel etkileri kapsamında bütünleyici bir bakış açısıyla da gözden geçirmek gerekir.

Dilin uzlaşımsal karakteri hiç şüphe yok ki, bizi dilin toplumsal yönünü ele almaya iten en önemli unsurdur. Dilin toplumsal yönünü ortaya koyan uzlaşım, Locke için her şeyden önce sağduyulu bireyleri gerektirir. Çünkü dil, öncelikli olarak sağduyulu bireylerin bir güven duygusu içerisinde bir araya gelmesini ifade etmektedir. Güven duygusu, sözcüklerin bildirişim içinde kullanımına imkan tanıyan en önemli unsurdur. Bu temel varsayımdan hareketle, Locke'un dil anlayışında, bildirişimin ancak, insanların birbirlerine duydukları güvenle korunan, iki yönlü bir sözleşme sayesinde mümkün olabildiği ifade edilebilir(Dawson, 2007:287-288). Bu söz konusu sözleşmelerden ilki semantik sözleşmedir ve bu sözleşmede, insanlar birbirleriyle belli bir ses grubunun belli bir ideyi göstermesi gerektiği konusunda aralarında bir uzlaşım’a varmaktadır.

2 Locke'un Deneme'sinin Türkçe versiyonunda kimi kısımlara yer verilmemiş olmasından ötürü, zaman zaman eserin İngilizce versiyonuna başvurulmuştur. Bkz. John Locke, An Essay Concerning Human Understanding, Volume II, MDCXC, Based on the 2nd Edition, Books 3 and 4, (III.x.12), s. 248-249. 
Bildirişimdeki bu söz konusu sözsüz ve yazılı olmayan karşılıklı rıza gösterimi, yani bu karşılıklı uzlaşım olmaksızın açıktır ki sözcükler hiçbir kamusal anlam taşıyamayacaklardır. Bu dilsel sözleşmenin diğer bir yönü ise moral bir sözleşmeye işaret eder. Dilsel sözleşmenin bu yönüyle, insanlar birbirlerinin zihinlerini dikkate alarak konuşma yönünde bir uzlaşı içine girmektedir. Nitekim bildirişim esnasında, sözcüklerin imlediği idelerin görülemez olan karakteri, bildirişim içerisinde kalmayı tercih ettiğimiz sürece, bizi insanların doğruyu söylüyor olduğu yönünde güven duymaya da zorlamaktadır. İşte, Locke'ta ancak güven kavramının desteklediği bu iki yönlü dolayım ile bildirişimin gerçekleştiği varsayılabilmektedir. Ayrıca, dilsel sözleşmenin bu ikili yönelimi, bildirişimin özsel mekanizmasını da ortaya koymuş olur. Bu bakımdan da dil içerisinde varsayılan bu iki yönlü sözleşme, aynı zamanda sağduyulu bireylerin toplumsal bireyler haline gelmesinde önemli bir başlangıç noktasını da teşkil edecektir. Tam da bu noktada, Locke'un toplumu aynı zamanda önceleyeceğini de göreceğimiz dil anlayışının toplumla olan ilişkisine yakından bakmak gerekir.

Bilindiği üzere Locke, insanların bir uzlaşı, yani karşılıklı bir rıza gösterimi içerisinde bir araya gelerek, kökensel bir anlaşma ile, yani bir toplum sözleşmesi ( Original Compact) ile gerçek anlamda bir sivil toplum içerisinde yaşamaya başladıkları düşüncesindedir. Ona göre, insanları böyle bir sözleşme yapmaya iten neden, doğa durumu olarak işaret ettiği durumun sakıncalarını gidermek, yani söz konusu durumda sahip olduğu haklardan bir ihlale maruz kalmaksızın yararlanabilmektir. Bu söz konusu Toplum Sözleşmesi'nin semantik karakterine değinmezden evvel, öncelikli olarak Locke'un doğa durumu olarak işaret ettiği durumu, toplum ve dil ilişkisi kapsamında değerlendirmek gerekir.

Locke'un doğa durumuna ait en açık ifadeleri şu şekildedir:

“Doğa durumu, herkes için bağlayıcı olan bir doğa yasasının yönetimi altındadır. Bu yasanın kendisi olan akıl, ona kulak verdiği takdirde tüm insanlığa, insanların eşit ve bağımsız olduklarını ve bu nedenle hiç kimsenin bir başkasının yaşamına, sağlı̆̆ına, özgürlüğüne ve mülkiyetine zarar vermemesi gerektiğini öğretir. (...) Benzer yetilerle donatılmış olduğumuz ve tek bir doğal topluluğu paylaştığımız için -aşağı türden yaratıkların bizim için yaratılmış olmasına benzer bir şekilde, biz de sanki başkaları için yaratılmışız gibi- aramızda, bize başkalarına zarara uğratma yetkisi veren herhangi bir bağımlılık ilişkisinin bulunduğu varsayılamaz. Herkes, 
nasıl ki kendisini korumak ve sahip olduğu şeyleri kendi iradesiyle bırakmamak eğiliminde ise, aynı nedenle ve kendi can güvenliği tehlikeye girmediği takdirde, insanlığın geri kalanını da elinden geldiğince korumalıdır(Locke, 2008:3-7)."

Böylece Locke'un doğa durumunun, bir özgürlük durumu olsa da sinırsız bir serbestlik durumu olmayacağı ortaya çıar. Henüz bir sözleşmenin yapılmadığı koşullar altında, doğal hakkın sınırlarını çizerek özgürlük ile sinırsız serbestlik arasındaki ayrımı tayin edecek olan şey, görüldüğü üzere 'aklın' ta kendisidir. Bu bakımdan da Locke'un doğa durumu anlayışında, insanların, kendi tutkularını kovalayan varlıklar olarak pekala barış içinde yaşayabilecekleri, çünkü doğa durumunda, iradenin gerekleri ile aklın gerekleri arasında herhangi bir çelişkinin bulunmadığı sonucuna ulaşılır. $\mathrm{Bu}$ da doğa durumundaki insanların, moral bakımından birbirlerinden yalıtılmış olmadıkları; aksine, onlar arasında doğa yasası tarafından kurulan akılsal ve moral bir bağın bulunduğu, yani doğa durumunun bizzat bir sosyal durum olduğu anlamina gelir(Tekin, 2002:321). O halde Locke'un, hem varsaydığımız bu iki yönlü dilsel sözleşmesini, hem de doğa durumuna ilişkin açılamasında benzer yetilerle donatılmış olduğumuza yaptığı vurguyu dikkate alarak doğa durumundaki bu sosyal durumun aslında bizzat dilin dolayımıyla kurulmuş olan akılsal ve moral bir bağa işaret etmekte olduğu sonucuna ulaşılabilinir. Çünkü bu söz konusu akılsal ve moral bağ, her şeyden önce toplumda ortak bir dil'in kullanımin gerektirmektedir.

Ayrıca Locke'un doğa durumu tasvirinde akılsallık ve iradenin birbirini dışlamadığı aksine, Tanrı'nın koymuş olduğu doğa yasası gereği, birlikte uyum içerisinde olmak durumunda oldukları göz önünde bulundurulduğunda, Locke'un uzlaşımsal dil anlayışının temellerine ilişkin bir takım çıkarımlara ulaşmak da mümkün olur. Locke'un, kendi dil felsefesi içerisinde dilin uzlaşımsal doğasına pek çok kez vurgu yapmış olmasına karşın, bu uzlaşımsallığın nasıl ve ne şekilde gerçekleşmekte olduğuna dair bir açıklaması bulunmamaktadır. Oysa Locke'un doğa durumunda görebileceğimiz üzere, irade ve akılsallığın birbirini dışlamadığı, aksine bir uyum içerisinde olmak durumunda oldukları düşünüldüğünde, dilin mevcudiyetini mümkün kılan uzlaşımsallığın da bu söz konusu uyumun kendisinden kaynaklaniyor olduğu sonucuna ulaşılabilinir. O halde Locke'un, dilin uzlaşımsallığını çatışmacı bir karakterde değil de, akılsallığın ve iradenin uyumunun ve birlikte iş görüyor olmalarının kendiliğinden ortaya çıan bir sonucu olarak 
gördüğünü ifade etmekte bir sakınca yoktur.

Locke'ta bildirişimin temelinde görülen bu iki yönlü sözleşme aynı zamanda, onda sağduyulu bireylerin toplumsal bireyler haline gelmesinde, önemli bir başlangıç noktasını da teşkil eder. Aklın ve iradenin uyumunun bir sonucu olarak, doğa durumunda ortaya çıkan dil dolayımı ile kurulan akılsal ve moral bağın bir sonucu olarak insanlar arasında gelişen güven duygusunun, Locke'taki bir sonraki aşaması, onun Toplumsal Sözleşme'ye dayanak oluşturmasıyla kendini gösterir(Dawson, 2007:290-291). Böylece de bildirişimin imkanını sağlayan dilin uzlaşımsal temeli, Locke için sağduyulu bireyleri bir araya getirerek toplumun kendisinden söz etmeyi mümkün kıldığı gibi, bir sonraki aşamada da kişilerin kendi güvenliği ve toplumun refahı için dilin kendisinde temellenen güven duygusu temelinde, tek bir toplum oluşturmak üzere "toplumsal sözleşme" ile bir araya gelmelerinin de yolunu açmıs olur. Kaldı ki Locke'un, hem herkesin birbirine güven duyup rıza göstererek katıldığı̆, başkalarıyla tek bir toplum oluşturacak şekilde birleştiği toplum sözleşmesinden, hem de toplum ve yönetim arasındaki ilişkiyi tarif ederken "güven" kavramına sıkça başvurduğu da bir gerçektir. O halde, güven duygusun bir sonucu olan bu toplumsal sözleşme, bildirişim temelinde hem bir semantik sözleşmeyi, hem de moral bir sözleşmeyi ifade etmektedir(2007:289). Kendi ortak iyilerinin korunması çerçevesinde bir araya gelen topluluğun öncelikli olarak belli başlı kavramlar çerçevesinde bu ortak iyileri açık bir şekilde ortaya koyması ve ardından da açık kılınmış bu kavramların içerimlerine dair aynı düşünceleri benimseyip devam ettireceğine de dair belli bir kabul içerisinde bulunması böylece, bu toplumsal sözleşmenin temeli olarak ortaya çıkmaktadır. Uzlaşımsal dilin insanlar arasında varettiği güven duygusunun dayanak olduğu bu sözleşme, devamlılığının sağlanması söz konusu olduğunda da, ancak yine sadece uzlaşımsal dilin mevcudiyetini sürdürerek kavramların anlamlarında sabitleyici bir etki sağlayabildiği müddetçe geçerliliğini koruyacak bir yapıdadır da.

\section{4) Locke'ta Dil, Toplum ve Uzlaşım Arasındaki İlişkiler}

Locke'ta dil, toplum ve uzlaşım arasında ortaya konulan ilişkinin doğru bir değerlendirimini yapmak için bu ilişkin bir de diğer yüzüne bakmak gerekir. Çünkü Locke'un dil anlayışındaki uzlaşımsal karakter, bir yönü ile de yıkıcı ve güveni tehdit edici bir yönelime de sahip olabilmektedir. Nitekim Locke' un insanların bu bahsedilen dilsel sözleşmeye karşı saygı duymalarını ifade eden doğal isteğin kendisine çeşitli metinlerinde şüphe 
ile baktığı net bir şekilde görülür. Örneğin, Siyasal Toplumun ve Hükümetin Amaçları Üzerine adlı bölümde Locke'un şu ifadelere yer verdiği görülür:
“(...) doğa durumunda, yerleşik yasalara göre bütün uzlaşmazlıklar konusunda karar verme yetkisiyle donatılmış, bilinen ve tarafsız bir yargıcın eksikliği söz konusudur. Doğa durumundaki her kişi, hem yargıç, hem de doğa yasasının uygulayıcısı olduğundan ve insanlar, kendilerine karşı taraflı olduklarından, insanların kendi olaylarında, hırs ve intikamın, aşırı kızgınlıkla birlikte, insanları aşırı derecede ileriye götürme eğiliminde olması büyük olasılıktır. Oysa insanlar, diğer insanlar söz konusu olduğunda, ihmalkar ve düşüncesiz olduklarından, bir o kadar aşırı ağır olmaya yatkındırlar(Locke, 2008:40-41)."

Buna istinaden, bir de Locke'un Deneme'sinin üçüncü kitabının özellikle X. bölümü olan Sözcüklerin Kötü Kullanılması'na dair olan kısım incelendiğinde bu şüphenin kendisini daha da belirgin kıldığı görülür:

\begin{abstract}
“Dilde doğal olarak bulunan kusurlarla, sözcüklerin kullanımındaki kaçınılması zor olan karanlık ve bulanıklıklardan başka, iletişim alanında insanların bilerek yaptıkları birçok yanlış ve savsama da vardır ki, bunlar, bu imleri bakımından doğal olarak zorunlu olana göre çok daha az açık ve seçik yaparlar. ... Sözcükler benim idelerimi başkalarına bildirmek için kullanıldığına ve bunu doğal bir imlemle değil de benim istençli uygulayışımla yapacaklarına göre, bunlara kimi kez bir şeyin kimi kez de başka bir şeyin yerini tutturduğum zaman, bu açlk bir aldatmaca ve kötü kullanma olur; isteyerek yapıldığı zaman da bu ya büyük bir zihinsel yetersizliğe ya da daha büyük bir ayıba bağlanabilir(Locke, 2004:339-340)."
\end{abstract}

Locke'a göre böylece, insanların bilinçli ya da bilinçsiz olarak kendilerine ve de diğerlerine söyledikleri yalanlarla, bildirişimin temelinde bulunan bu semantik ve moral sözleşme de ihlal edilmiş olur. Bu da içten içe, insanların birbirine duydukları güven duygusunun, yani toplumun temellerinin aşınmasına neden olur. Bu iki yönlü dilsel sözleşmenin birbiri ardına ihlali, insanı kullandıkları sözcüklere karşı şüpheli hale getirdiği gibi, sivil yapıya da zarar vermeye başlar. Nitekim insanların bencillik ve tarafgirliklerinin tespitini, daha doğa durumunda yapmış olduğu için Locke, bu barış ve iyi niyet durumunun insanların bu özelliklerinden ötürü bir süre sonra savaş durumuna dönüştüğünü 
ifade etmekte gecikmez. Locke, herkesin elinde doğa yasasını yürütme gücünün olmasının, insanların tarafgirlik, bencillik gibi niteliklerinden dolayı haksızlık yaratabileceğini kabul eder(Locke, 2008:4-5). Bu haksızlık gerçekleştiğinde doğa yasası ihlal edilmiş olur, çünkü yasa haksızlık yapılmamasını buyurmaktadır. Çünkü akıl, ona başvuracak olan bütün insanlığa, hepsi eşit ve bağımsız olan insanlığa, hiç kimsenin bir başkasının yaşamına, sağlığına, özgürlügüne ya da mülkiyetlerine zarar vermemesi gerektiğini öğretir(Locke, 2008:6). Dolayısıyla yasayı ihlal eden, yasayı inceleme ve keşfetme görevinden habersiz olan ya da bencil isteklerinden dolayı başkasına haksızlık yapandır(2008:6). O halde açıktır ki, insan her ne kadar akıl ve irade sahibi ise de Locke'a göre, bencilce ve tarafgirce de davranabilmektedir. Bunu en açık haliyle, kişinin sözcükleri bilinçli bir şekilde kötüye kullanması örneğinde de görebiliriz.

Locke için, insanların her zaman akla uygun davranmamaları nedeni ile doğa durumunda ortaya çıkabilecek olan şiddet ve savaş durumuna son verebilmek için ortak bir yargıca ihtiyaç duyarak sivil topluma geçmeleri de bu söz konusu tabloyu değiştirmez. Her ne kadar Locke'un politik teorisinde akla uygun bir hak, yine aynı akla uygun bir başka hakla ve görevle çelişmese de irade sahibi insanın, sivil toplum kurulduktan sonra bile zaman zaman, aklın gereklerine uymadan hareket edebildiği de görülmektedir. Locke'ta bunun en açı örneği, onun haksız güç kullanan yönetimden bahsettiği yerdir. Locke'un sözünü ettiği bu haksız güç ise, "ortak iyi" kavramının içeriğinin zedelenmesi ile ortaya çıacak olan bir durumun tasvirine işaret eder(Dawson, 2007:292). Toplumun ortak iyisini gerçekleştirmek ve devamlılığını sağlamak üzere kurulan yönetim, ancak bu söz konusu ortak iyinin içeriğini boşaltarak, onun içine kendi iyisini bencilce yerleştirmeye başladığı andan itibaren haksız bir güç kullanmaya başlar. Bu da Locke'un ifadeleri ile "sözcükleri kötüye kullanarak" eylemenin en açık ifadesidir. O halde, insanları kullandıkları sözcüklere karşı şüpheli hale getiren bu durumun sivil yapıya zarar veren halini önlemenin tek yolu Locke’a göre, insanların dilsel sözleşmede, yani dilin gerektiği gibi kullanımı yönünde vardıkları uzlaşmadan dönmeyerek veya bunun aksine hareket etmeyerek aralarındaki güven duygusunu korumaktan geçmektedir.

Locke'un politika felsefesinde dilin var ettiği karamsar bir tabloyu tercih etmemek için, onun, sivil topluma geçişin nedenleri arasında her ne kadar ortak bir yargıcın yokluğu ve kıtlık gibi sebeplerden bahsetmiş olsa da, bu konudaki asıl vurgusunun insanların aklın gereği olarak sivil 
topluma yöneliyor olmaları üzerine olduğu hatırlanmalıdır. Böylece Locke'ta, insanların iradelerini akılları gereği, üzerinde uzlaşmaya vardıkları dil aracılı̆̆ 1 ile, sadece kendi iyilerini değil de tüm insanların iyilerini, ortak bir iyi altında korumaya ve devam ettirmeye yönelik olarak, -her ne kadar zaman zaman onun bu konuda şüpheye düştügü görülse de- kullanabilecekleri de düşünülebilir. Bu ileri sürüme daha yakından bakabilmek içinse, Locke tarafından ortaya konulan bu akılsallık kavrayışını kısaca irdelemek gerekir.

Locke, doğa durumunun herkes için bağlayıcı olan bir doğa yasasının yönetimi altında bulunduğunu dile getirerek söz konusu yasadan kaynaklanan yükümlülüklerin, tam da doğa durumunda, yani insanlar arasında herhangi bir tabiyet ilişkisinin bulunmadığı ve egemenliğin tesis edilmiş olmadığ 1 koşullar altında da geçerli olduğunu ileri sürmekteydi. Onun tam da bu iddiası, akılsallığın statüsü ile ilgili bir tartışmayı zorunlu kılar; çünkü doğa yasasının, bir egemen güç tarafından teminat altına alınmış olmadığı halde tüm insanlık için bağlayıcı olduğunu söylemek, yasayı yasa yapan şeyin otorite değil, akılsallık olduğunu, yani akılsallığın kendisi bakımından bağlayıcı olduğunu söylemektir(Tekin, 2011:133). Ne var ki -bizzat Locke'un sözlerini yineleyecek olursak- herkesin tüm yapıp etmelerini "kendi yaşamını ve varlığını muhafaza etme yönündeki güçlü arzunun" etkisi altında gerçekleştirdiği; yani insan eylemlerinin "iyi yaşamla" değil, "yaşamın kendisi" ile ilgili bir nitelik taşıdığı; dolayısıyla iradenin merkezi kategori olduğu modern koşullarda, akılsallı̆̆ın kendisi bakımından bağlayıcı olması ne kadar mümkündür? Başka bir deyişle, irade ve akıl arasındaki ilişkiyi, doğal bir uyum ilişkisi olarak kavramak mümkün müdür? İnsanın yaratmış olduğu uzlaşımsal dil, irade ve akıl arasında varsayılan bu uyum ilişkisi dolayısıyla artık kendini yanlış ve yanıltıcı kullanımlara kapatmış mıdır? Ya da, bu yine dilin bir aldatmacasindan $\mathrm{m} i$ ibarettir?

Bakıldığında Locke tüm bu sorular çerçevesinde, "yaşamın kendisini", temel ihtiyaçların karşılanması esasından hareketle ele alarak, irade kategorisini yeni bir zeminde tanımlamış görünür. Böylece Locke, irade ve akılsallık arasındaki ilişkiyi doğal bir uyum ilişkisi olarak kavramaya çalışmışsa da bu uyumun, dil konusu ele alındığında, -onun bu söz konusu uyum ilişkisi ile oluşturulması dışında- kullanımı ile gözden geçirildiğinde, hala yanlış ve aldatıcı kullanımlarının mevcut olması dolayısıyla, zaman zaman bencil iradelerin lehine çevrilmekte olduğuna da dikkat çekmeyi çekmeyi ihmal etmez. Bu bakımdan da Locke'un 
anlayışında dil, bu söz konusu uyumu hem var ediyor olan, hem de onu yok edebilecek tehditkar bir olgu olarak karşımızda durur ve bu uyum hakkındaki şüphelerimizi körüklemeye devam eder.

Locke'ta dilin, akıl ve irade arasındaki uyumu bozabilecek yapısını, onun semantik değişkenlik problemi ele alınarak daha açık kılınmaya çalışıldığında, bunun çok daha tehditkar ve yıkıcı sonuçlara kadar götürebileceği görülür. Bilindiği üzere Locke, imlemeyi konuşan kişinin ideleri ile sınırlandırması dolayısıyla, sözcüklerin kendilerine bağlandığı idelerin nüfuz edilemez öznelliği yüzünden, her bireyin radikal biçimde özel bir dile sahip olabileceği yönünde bir sonuçla bizi karşı karşıya bırakmaktadır. Bu durum ise, farklı insanlar için, sözcüklerin farklı anlamları imlemekte olduğu yönünde bir tür semantik değişkenlikle sonuçlanmaktadır. Locke bu semantik değişkenlikle başa çıkabilmek için, idelerin zihinler arası özdeşliğini, gösterge aracılığıyla ve uzlaşım'a dayanarak yaklaşık olarak çözümlemeye çalışır. Böylece uzlaşım anlayışının Locke'ta, ideleri yaklaşık da olsa birbirine eşdeğer kıldığı varsayılır. Bu haliyle Locke'un ancak yaklaşık olarak çözüme yakınlaştırabildiği semantik değişkenlik konusu, bugün dahi nadiren de olsa cisimleşen bir hayalet olarak karşımızda durmaktadır.

Semantik değişkenlik problemiyle yüzleşmek durumunda kaldığımız yerin, daha çok kültürel yaşamın kurucusu olarak görülen karışık kipleri imleyen sözcüklerimizin kendisi olduğu dikkate alındığında ve onların evlilik, piyasa ve zinadan, yönetim, hırs ve devrime kadar tüm "doğal olmayan" deneyimlerin her yönünü düzenlemekte ve ifade etmekte olduğu gözetildiğinde, bu sosyal etkileşim ve gelişim kanallarının anlamlarının bugün bile hala tartışılıyor olması şaşırtıcı gelmemelidir. O halde Locke'un da ifadeleri ile diyebiliriz ki, toplumun en temel biçimlerinde bile gerekli olan dil, bu son derece önemli araç, toplumun ortak bağının kendisi, aslında kusurlu bir yapıdadır. Bu haliyle de dil, zaman zaman toplumun devamlılığını tehlikeye sokucu bir nitelik de taşıyabilmektedir.

Öte taraftan, karışık kiplerin özlerinin, yani anlamın zihin tarafından keyfi biçimde, herhangi bir dişsal kalıba veya gerçek varoluşa bağlı olmaksızın, uzlaşımsal olarak dilin gereklerine uygun olarak, bildirişime elverişlilik ve yararlılık motivlerince bireysel iradeler tarafından bütünüyle dil içinde yapılandırılması dolayısıyla da, Locke'un anlamın geliştirilmesine ve değiştirilmesine ilişkin olarak daha toplumsal bir 
hikayeye işaret ediyor olduğunu gözden kaçırmamak da gerekir. Bu da belki, bizi, yukarıda aktardığımız tablo ile ilgili olarak çok da karamsar olmamamız yönünde motive edebilir. Anlamın üretilmesine ilişkin olarak bu haliyle de daha toplumsal bir anlatı içerisine girdiğini gördüğümüz Locke, farklı dillere ilişkin yapmış olduğu gözlemlerden hareket ederek, bu farklı dillerde birbirine çevrilemeyen sözcükler bulunması olgusu dolayısıyla, her dil topluluğunun kendine özgü değer ve gelenek-görenek çerçevesinde anlam üretiyor olduğuna işaret eder: "Bir ülkedeki insanlar, gelenekleri ve yaşama tarzları yüzünden, başka ülkedeki insanların özgül ideler içinde toplamadıkları birçok bileşik ideler yapma ve bunlara adlar verme gereği duymuşlardır(Locke, 2004:310-311)."

Locke'un dil felsefesine bu açıdan bakıldığında da, onun semantik değişkenliği, toplumun kendine özgü olan değer ve gelenek-görenek potasında eritmeye çalıştığı belirtilebilir. Ayrıca Locke'un politika felsefesinde, -her ne kadar problematik bir görüntü arz etse de- özellikle sivil toplumun nasıl oluşturulacağı ve devam ettirilebileceğine yönelik yazılarında, semantik değişkenliğin kendisine meydan okumakta olduğuna da tanık olunur. Nitekim Locke, toplumun ortak refahindan, adaletten, hoşgörüden, yönetimden, ortak yargıçtan bahsederken bu kavramları şüpheyle değil, anlamlarından gayet emin şekilde ele almakta ve incelemektedir.

Locke'un anlayışında semantik değişkenliğin bir kenara bırakıldığının en önemli göstergelerinden biri de, bireylerin ortak bir dil ile varmış oldukları bir uzlaşı temelinde yönetimi inşa ederek "ortak iyilerini" oluşturmalarında kendini gösterir. Ancak bu ortak iyi'nin semantik çerçevede belirleniminden sonradır ki insanlar, kendi "doğal güçler"inden vazgeçip, açık ya da örtük bir şekilde güven göstererek, bu ortak iyi'nin korunması görevini bir yöneticiye devrederler. İşte dilin ancak bu uzlaşımsal karakteri aracılığı ile tespiti ve tesisi sağlanan ortak iyi'nin korunması koşuluyla, insanlar doğa yasası gereği sahip oldukları hakları vekillerine devredebilmektedir. Ortak iyinin belirlenmesi gerektiğinde, onun öğretisinde başlangıçtan bugüne kadar ki sayısız anlar dikkate alınarak insanların ve onların yöneticilerinin zihinlerinin, sayısız yorumlarının nasıl gözden geçirebileceği sorusu her ne kadar bir sorun teşkil ediyor görünse de, Locke'un yine de sivil toplumun gerek tesisinin gerekse de devaminin, akıl ve iradenin uyumunun bir sonucu olarak karşımızda duran dilin uzlaşımsal karakteri ile mümkün kılınacağı düşüncesinde olduğu açık bir şekilde belirtilebilir. $O$ halde politik 
yaşamın özsel başlangıç noktasının, zaman zaman bu konuda şüpheye düşse de Locke için, ortak bir anlayışın, yani uzlaşımın kendisinden meydana gelmekte olan dilsel eylemlere bağlı olduğunu kabul etmek gerekir. Bunun aksi olsaydı ve Locke'un arada inkar ettiği gibi bizler de dilsel eylemlerdeki bu ortak, uzlaşımsal anlayışı inkar etseydik, şüphesiz onun anlayışında politik bir yapı olan toplumun kumdan bir kaleden farkı kalmazdı.

Böylece Locke'un dil görüşünde belirleyici bir unsur olarak ortaya çıkan uzlaşımsallık kriterinin, özellikle onun politika felsefesi söz konusu olduğunda sivil toplumun kurulumu aşamasında, semantik değişkenliğin bir kenara birakılarak ortak iyi'nin tespitinde kurucu bir rol üstlenmekte olduğu ortaya çıkmıştır(Dawson, 2007:295). Bu bakımdan Locke'un politika felsefesinin kolektivist izler taşıdığını da ileri sürmekte bir sakınca yoktur. Locke'un çalışmaları birbirinden soyutlanmış bir şekilde değil de, bir bütün içerisinde değerlendirildiğinde, yani dil felsefesinden hareketle politika felsefesine bakıldığında onun politika anlayışındaki toplumsal unsurların çoğu zaman gözden kaçırıldığı belirtilebilir. Politika felsefesi gözetildiğinde Locke'un bireyciliği, bireylerin mantıksal olarak toplumu öncelemesi anlamında olmak üzere, eş deyişle metodolojik bir anlamda değerlendirilmelidir(2007:294). O halde Locke'un politika anlayışında metodolojik anlamda bir bireyci olduğunu söylemek, onun aynı zamanda bir tür kolektivist olduğunu söylemeye engel de teşkil etmeyecektir. Locke'un dil anlayışı gereği politik anlayışında bir yönüyle de kolektivist olarak düşünülmesi gerektiğinin en büyük nedeni, hem dilin oluşmasında hem de bu dilin varettiği kavramlar çerçevesinde ortak iyi' nin belirlenimi esnasında, insanların aşırı bencil arzularını bir kenara bırakıp bir uzlaşım'a varmaları olarak gösterilebilir.

\section{Sonuç}

Locke'un sözcüklerin kurulumuna ayırdığ1 bölümde, dilin en ayırt edici özelliği olarak karşımıza onun uzlaşımsal, yani toplumsal karakteri çıkmaktadır. Locke'un dil anlayışında sözcükler ile ideler arasındaki bağlantının bir parçası olarak ortaya çıkan bu uzlaşımsallık unsuru, Locke'un sağın bilgiye erişmedeki amacında ilk elde her ne kadar dildeki bir yetersizlik olarak ortaya konmuş da olsa, gerek yine de bu imkana yaklaşmayı sağlayacak tek unsur olarak düşünülmesi, gerekse de iletişimin imkanını sağlamasıyla oldukça önemli bir konumda bulunur. Locke'un dil felsefesinde iletişimin birliğini kuran bu uzlaşımsallık 
karakteri incelendiğinde, onun anlayışında hakikat, bilgi ve anlam söz konusu olduğunda onların varlıklarını gerçek varoluşun bir iz düşümünü veren gösterilenlere borçlu olduğu kadar, bu birliği kuran uzlaşımsallığın kendisine de borçlu olduğu açık bir şekilde ortaya çıkar.

Dilin en ayırt edici özelliği olarak ortaya çıkan, bu uzlaşımsal karakteri aynı zamanda, insanları bir güven duygusu etrafında bir araya getirip, karşılıklı bildirişimi mümkün kılması bakımından bir anlamda toplumun kendisini de öncelemektedir. $O$ halde, Locke'un ortaya koyduğu uzlaşımsallık ekseninde, dil ve toplumu birbirinden ayrı düşünmenin imkansızlığı da ortadadır. Belirtilmelidir ki, Locke'ta toplum olmanın en önemli ve öncelikli basamağı, kişilerin semantik bireyselliklerini bir kenara birakmak suretiyle, ortak bir dilin yaklaşık da olsa semantik uzlaşımsallığında buluşmayı kabul etmeleri olarak ortaya çıkar. Ayrıca, yine Locke'un sivil toplumun oluşumunda "toplumsal sözleşme" olarak işaret ettiği anlaşmanın, bir yönüyle de semantik bir anlaşmaya işaret ettiği göz önünde tutulduğunda, onun devamlılığını sağlamanın da “dildeki uzlaşımsallığa sadık kalmak(Locke, 2004:354-355)" suretiyle onu iyi kullanmaktan geçtiği de kabul edilebilir.

Locke'un hem dil felsefesini, hem de toplumu irdelediği politika felsefesini gözeten bütünleyici bir bakış açısıyla şu belirtilebilir ki, onun dil, akıl ve irade üçgeninde toplum kavramına bir açıklık getirmesini mümkün hale getiren en önemli unsur, aklın ve iradenin dilin uzlaşımsallığı, eş deyişle bildirişimin imkanı lehine bir sonuç doğurmuş olmasıdır. Locke zaman zaman şüpheye düşmüş görünmekteyse de, yine de sadece sağ duyulu bireylerin akılları ve iradeleri gereği ortak bir dilin bütünleştirici ve uzlaştırıcı yapısında bir araya gelmeleri ile toplumun kendisinden söz edilebileceğinin farkındadır. Bu bakımdan Locke'un sivil toplum inşasının her ne kadar bireysel unsurların izlerini taşıdığı vurgulansa da, dil felsefesi göz önünde bulundurulduğunda "uzlaşımsallık" ekseninde bu toplum inşasının, bir yönüyle de inkar edilemeyecek bir şekilde, kolektivist bir yön taşımak durumunda olduğu da gözden kaçmamalıdır.

Sonuç olarak, Locke'un hem dil felsefesinin hem de politika felsefesinin uzlaşımsallık kriteri dolayısıyla ortak bir amaçta buluştukları varsayılabilir: Dili uzlaşım temelinde düzenleyerek sözcüklerin yanlış ve yanıltıcı soyut genelliğinden kurtulup "sağın bilgi"ye ulaşmak suretiyle iyi düzenlenmiş "ideal" bir topluma ulaşabilmek. 


\section{Kaynakça}

Aaron, R. (1963). John Locke, Oxford Clarendon Press, Oxford.

Altuğ, T. (2011). Dile Gelen Felsefe, YKY, Cogito: İstanbul.

Dawson, H. (2007). Locke, Language and Early-Modern Philosophy, Cambridge University.

Locke, J. (2004). İnsan Anlığı Üzerine Bir Deneme, çev. Vehbi Hacıkadiroğlu, Kabalcı Yayınevi.

Locke, J. (2008). Second Treatise of Goverment, pdf: www.earlymoderntexts.com> locke1689a

Magee, B. (2000). Büyük Filozoflar, Platon'dan Wittgenstein'a Batı Felsefesi, çev. Ahmet Cevizci, Paradigma.

Nayak, B. K. (2003). Locke, Berkeley, Hume and Augustine, A Study in the Philosophy of Language, Anu Books, Shivaji Road, Meerut, India.

Ott, W. R. (2004). Locke's Philosophy of Language, Cambridge University Press. 